\title{
PENGARUH PENDIDIKAN KEWIRAUSAHAAN DAN LINGKUNGAN KELUARGA TERHADAP NIAT MAHASISWA UNTUK BERWIRAUSAHA
}

\author{
Popi Fauziati ${ }^{1}$, Karmila Suryani ${ }^{2}$ \\ ${ }^{1}$ Program Studi Akuntansi, Fakultas Ekonomi dan Bisnis, Universitas Bung Hatta, Jalan Bagindo \\ Azizchan, Aia Pacah, Padang \\ ${ }^{2}$ Program Studi Pendidikan Teknik Informatika dan Komputer, Fakultas Keguruan dan Ilmu \\ Kependidikan, Universitas Bung Hatta, Jalan Bagindo Azizchan, Aia Pacah, Padang \\ e-mail: popifauziati@bunghatta.ac.id
}

\begin{abstract}
Abstrak
Tujuan penelitian untuk membuktikan pengaruh pendidikan kewirausahaan dan lingkungan keluarga terhadap niat mahasiswa untuk berwirausaha di Universitas Bung Hatta, Padang. Metode penelitian adalah metode kuantitatif yang didasarkan pada filsafat positivisme untuk menggambarkan dan menguji hipotesis penelitian. Populasi penelitian adalah mahasiswa aktif yang terdaftar tahun 2019 di Universitas Bung Hatta dan metode penyampelan yang dilakukan adalah purposive sampling. Data penelitian dikumpulkan menggunakan google form dan jumlah responden yang berpartisipasi dalam penelitian sebanyak 140 orang mahasiswa. Pembuktian hipotesis dilakukan dengan regresi berganda. Hasil penelitian menunjukkan bahwa pendidikan kewirausahaan dan lingkungan keluarga berpengaruh terhadap niat berwirausaha.
\end{abstract}

Kata Kunci: lingkungan keluarga, niat berwirausaha, pendidikan kewirausahaan.

\begin{abstract}
The purpose of this research was to prove the effect of entrepreneurship education and family environment on students' intention to become entrepreneurs at Bung Hatta University, Padang. The research method was a quantitative based on the philosophy of positivism to describe and test research hypotheses. The research population was active students enrolled in 2019 at Bung Hatta University and the sampling method used purposive sampling. Research data were collected using Google Form and the number of respondents who participated in the study were 140 students. Proof of hypothesis is carried out by multiple regression. The results showed that entrepreneurship education and family environment influence entrepreneurial intentions.
\end{abstract}

Keywords: family environment, entrepreneurial intentions, entrepreneurship education.

\section{PENDAHULUAN}

Lulusan diploma dan sarjana masih mendominasi angka pengangguran terbuka pada tahun 2019 di Sumatera Barat yang mencapai 10,86\% dan 7,46\% dari total angkatan kerja sebesar 2,69 juta orang (Badan Pusat Statistik, 2019). Pengangguran tersebar di perkotaan dan pedesaan dengan jumlah pengangguran di perkotaan lebih medominasi dibandingkan di daerah 
pedesaan. Berdasarkan data Badan Pusat Statistik (BPS) tersebut, angka pengangguran tertinggi di Sumatera Barat berada di Kota Padang yang mencapai 9,18\%. Angka tersebut terlihat dari data tingkat pengangguran tahun 2017 sampai 2018. Berikut data tingkat penggangguran di Sumatera Barat pada tahun 2017 dan 2018 .

Tabel 1 Persentase Tingkat Pengangguran di Sumatera Barat Tahun 2017 dan 2018

\begin{tabular}{lcc}
\hline \multirow{2}{*}{ Kabupaten/Kota } & \multicolumn{2}{c}{ Tingkat Pengangguran $(\boldsymbol{\%})$} \\
\cline { 2 - 3 } & $\mathbf{2 0 1 7}$ & $\mathbf{2 0 1 8}$ \\
\hline Kab. Kep. Mentawai & 1,96 & 2,27 \\
Kab. Pesisir Selatan & 5,95 & 5,85 \\
Kab. Solok & 6,05 & 5,92 \\
Kab. Sijunjung & 3,32 & 3,20 \\
Kab. Tanah Datar & 3,72 & 3,86 \\
Kab. Padang Pariaman & 6,65 & 6,90 \\
Kab. Agam & 4,23 & 4,82 \\
Kab. Lima Puluh Kota & 2,60 & 2,70 \\
Kab. Pasaman & 6,81 & 5,88 \\
Kab. Solok Selatan & 5,54 & 5,85 \\
Kab. Dhamasraya & 3,69 & 3,94 \\
Kab.Pasaman Barat & 3,99 & 3,94 \\
Kota Padang & 9,44 & 9,18 \\
Kota Solok & 5,88 & 5,97 \\
Kota Sawahlunto & 6,19 & 5,75 \\
Kota Padang Panjang & 5,43 & 5,28 \\
Kota Bukittinggi & 6,94 & 7,15 \\
Kota Payakumbuh & 3,45 & 3,78 \\
Kota Pariaman & 5,97 & 5,72 \\
\hline
\end{tabular}

Berdasarkan data pada Tabel 1, diperoleh gambaran bahwa Kota Padang memiliki jumlah penggangguran yang paling banyak. Jika dilihat dari tingkat pendidikan, pengangguran terdidik masih termasuk yang tinggi. Data BPS Sumatera Barat mencatat lulusan perguruan tinggi atau sarjana mendominasi angka tingkat penggangguran dengan jumlah $8,12 \%$ atau sekitar 212.744 orang dari total angkatan kerja 2,62 juta orang. Jika pada tahun 2016 pengangguran terdidik didominasi oleh lulusan SMA tetapi tahun 2017 dan 2018 bergeser ke menjadi lulusan diploma dan sarjana. Ada tiga penyebab tingginya tingkat pengangguran di level diploma dan 
sarjana, yaitu: (1) Keterampilan tidak sesuai dengan kebutuhan pasar kerja; (2) Ekspektasi penghasilan dan status yang lebih tinggi; dan (3) Penyedia lapangan kerja yang terbatas. Orientasi lulusan diploma dan sarjana adalah untuk menjadi pegawai pada perusahaan swasta dan institusi pemerintah sedangkan minat mahasiswa untuk berwirausaha masih rendah (Adi, 2016) .

Indonesia memiliki indeks kewirausahaan sebesar 3,1\% pada tahun 2018. Angka tersebut masih lebih rendah dari Singapura $(7,2 \%)$ dan Malaysia (5\%) (Kementerian Perdagangan, 2018). Untuk menggerakkan perekonomian secara produktif, dibutuhkan $2 \%$ pengusaha dari total penduduk, sedangkan secara kualitas peringkat kompetensi wirausahawan Indonesia sangat jauh tertinggal dibandingkan negara-negara maju dan berkembang lainnya (Komara, 2014). Pertumbuhan kewirausahaan dalam suatu negara dapat didorong dengan memberikan mata kuliah Kewirausahaan di tingkat perguruan tinggi (Zimmerer, 2002). Direktorat Jenderal Pendidikan Tinggi (Dikti) memberikan programprogram pendukung untuk melahirkan wirausaha muda baru, seperti Program Mahasiswa Wirausaha (PMW). PMW diharapkan dapat merubah mindset mahasiswa, dari pencari kerja menjadi pencipta lapangan kerja (Ratnasari, dkk., 2013).

Universitas Bung Hatta sebagai salah satu perguruan tinggi swasta di Kota Padang telah melakukan pemetaan tentang profesi lulusan selama 2 tahun. Tahun 2017, jumlah lulusan yang menjadi wirausaha sebanyak 66 orang dari total lulusan 970 orang $(6,8 \%)$ dan tahun 2018 yang menjadi wirausaha sebanyak 96 orang dari total lulusan 1.355 orang (9\%). Data tersebut menunjukkan bahwa lulusan Universitas Bung Hatta yang berprofesi sebagai wirausaha masih sangat rendah.

Niat mahasiswa untuk berwirausaha dipengaruhi oleh motivasi, pendidikan kewirausahaan, lingkungan, modal, teknologi, imbalan, dan kebebasan yang kemudian dikelompokan menjadi faktor internal, eksternal, dan kontekstual (Utami, 2016; Anggles dan Memarista, 2017; Haqq, dkk., 2018; Khoeriyah, dkk., 2019). Faktor internal adalah dorongan yang ada dalam diri wirausaha seperti kepribadian individu, kemauan, perilaku, dan kompetensi individu yang 
memberikan dorongan untuk berwirausaha. Faktor eksternal adalah dorongan dari luar diri wirausaha seperti kondisi keluarga, kondisi fisik, lingkungan ekonomi, dan kondisi dunia usaha. Faktor kontekstual adalah faktor selain internal dan eksternal, seperti pendidikan kewirausahaan, atmosfir akademik, dorongan sosial, dan dorongan lingkungan.

Suatu usaha yang dilakukan dengan sadar dan sistematis untuk meningkatkan taraf hidup atau sesuatu yang lebih baik adalah sebuah pendidikan kewirausahaan. Pendidikan tersebut akan mengkolaborasikan jiwa dan semangat kewirausahaan melalui kegiatan formal maupun informal yang dapat berupa pelatihan, workshop, focus group, dan lainnya (Basrowi, 2014). Proses kewirausahaan adalah kolaborasi ilmu dan seni. Bidang ilmu akan memberikan pengetahuan/teori tentang kewirausahaan secara konvensional sedangkan seni akan mengajarkan kreativitas dan inovasi yang dapat dikembangkan oleh wirausaha (Laine, et al., 2019). Beberapa penelitian terdahulu yang menguji pengaruh pendidikan kewirausahaan terhadap niat untuk berwirausaha dengan menggunakan sampel mahasiswa. Hasil penelitian tersebut menyimpulkan bahwa niat berwirausaha dipengaruhi oleh pendidikan kewirausahaan (Utami, 2016; Anggles dan Memarista, 2017; Chandra dan Budiono, 2019).

Lingkungan keluarga adalah faktor yang paling dominan untuk mendorong jiwa berwirausaha. Seorang anak akan menjadikan orang tua sebagai role model. Anak yang memiliki orang tua berprofesi sebagai wirausaha akan memiliki keinginan untuk berwirausaha juga atau anak yang memiliki orang tua seorang pegawai akan cenderung memilih profesi sebagai pegawai (Suharti dan Sirine, 2011). Terdapat beberapa penelitian yang menggunakan sampel mahasiswa untuk menguji pengaruh lingkungan keluarga terhadap niat untuk berwirausaha. Hasil penelitian tersebut memperlihatkan bahwa lingkungan keluarga berpengaruh terhadap niat berwirausaha (Utami, 2016; Khoir, dkk., 2019).

Berdasarkan fakta dan penelitian-penelitian terdahulu yang telah diuraikan, maka peneliti melakukan penelitian dengan tujuan untuk membuktikan pengaruh pendidikan kewirausahaan dan lingkungan keluarga terhadap niat mahasiswa untuk berwirausaha di Universitas Bung Hatta, Padang. 


\section{METODE}

Metode penelitian yang digunakan adalah metode kuantitatif dengan menggunakan data primer. Penelitian menggunakan data angka yang diawali dengan tahap pengumpulan, pengolahan, dan analisis data. Untuk mengumpulkan data, disebar kuesioner kepada responden penelitian. Populasi penelitian adalah mahasiswa aktif yang terdaftar di Universitas Bung Hatta dengan jumlah 7.087 mahasiswa. Metode penyampelan yang dilakukan adalah purposive sampling. Kriteria yang diterapkan terhadap sampel adalah mahasiswa yang aktif terdaftar pada tahun akademik Genap 2019/2020 dan telah mengambil mata kuliah Kewirausahaan. Berdasarkan rumus Slovin (Sugiyono, 2011) sampel yang diperoleh minimal sebanyak 100 responden. Kuesioner dirancang dengan pernyataan terstruktur dan dibuat menggunakan google form. Kuesioner terdiri dari 2 bagian yang akan dijawab oleh responden, yaitu: (1) Pertanyaan tentang identitas responden, yaitu nama, jenis kelamin, semester, dan rencana usaha yang akan dibuka; dan (2) Pernyataan tentang variabel yang diteliti (niat berwirausaha, pendidikan berwirausaha dan lingkungan keluarga).

Indikator pernyataan yang digunakan pada kuesioner dirujuk dari penelitian Utami (2016) dengan menggunakan skala Likert 5.

Tabel 2 Skala Likert untuk Kuesioner

\begin{tabular}{cc}
\hline Kriteria & Skor \\
\hline SS: Sangat Setuju & 5 \\
S: Setuju & 4 \\
N: Netral & 3 \\
TS: Tidak Setuju & 2 \\
STS: Sangat Tidak Setuju & 1 \\
\hline
\end{tabular}

Variabel niat berwirausaha diukur dengan 5 pernyataan yang meliputi keyakinan responden untuk menjadi wirausaha dengan berbagai alasan diantara untuk meningkatkan kesejahteraan, meningkatkan perekonomian, tidak perlu menjadi bawahan, bebas dalam mengambil keputusan bisnis dan menciptakan lapangan kerja. Pengukuran variabel pendidikan kewirausahaan meliputi 8 
pernyataan yang terdiri dari materi yang sampaikan, rasa ingin tahu, peningkatan kompetensi, pengetahuan kewirausahaan, menjadi diri sendiri, dan kreativitas.

Pengukuran variabel lingkungan keluarga terdiri dari 4 pernyataan yang meliputi dukungan keluarga, didikan orang tua, dukungan ekonomi, dan kebebasan dalam memilih karier sesudah lulus dari perguruan tinggi. Sebelum dilakukan pengujian hipotesis, data yang dikumpulkan akan diuji kualitasnya yang meliputi uji validitas, uji reliabilitas, dan uji asumsi klasik (uji normalitas, uji multikolinieritas, dan uji heteroskedastisitas). Uji validitas ditujukan untuk menentukan suatu set dimensi yang disebut faktor dari hubungan antar variabel. Faktor akan dinyatakan valid apabila nilai factor loading lebih dari 0,4 dan nilai Kaiser Meyer Olkin Measure of Sampling Adequacy (KMO-MSA) lebih dari 0,5. Uji reliabilitas ditujukan untuk menentukan konsistensi dan bebas dari kesalahan dari jawaban responden. menguji instrumen agar hasilnya konsisten. Indikator sebuah instrumen dinyatakan reliabel adalah nilai Cronbach's Alpha lebih besar 0,6 (Ghozali, 2013).

Uji normalitas data bertujuan untuk menentukan nilai residual dalam model regresi berdistribusi normal. Data berdistribusi normal jika nilai signifikansi uji Kolmogorov-Smirnov > 0,05 dan data menyebar di sekitar garis diagonal dan mengikuti arah garis diagonal atau grafik histogramnya. Pengujian multikolinieritas ditujukan untuk menguji korelasi antarvariabel bebas dalam model regresi. Variabel bebas dari multikolinieritas apabila nilai tolerance < 0,10 atau $=$ nilai $\mathrm{VIF}<10$. Pengujian heteroskedastisitas ditujukan untuk menilai ketidaksamaan variance dalam model regresi. Model regresi dinyatakan bebas heterokedastisitas apabila sig. pada uji glejser $>0,05$ dan scatter plot menghasilkan titik-titik yang tidak membentuk pola tertentu serta menyebar di atas dan di bawah angka nol sumbu Y. Untuk pengujian hipotesis penelitian dilakukan pengujian dengan regresi berganda (Ghozali, 2013).

\section{HASIL DAN PEMBAHASAN}

Demografi responden menunjukkan jumlah responden laki-laki sebanyak 42 orang $(30 \%)$ dan perempuan 98 orang $(70 \%)$. Responden yang berada di 
semester 2 sebanyak 55 orang (39,3\%), semester 4 sebanyak 65 orang $(46,4 \%)$, semester 6 sebanyak 15 orang (10,7\%), dan semester 8 sebanyak 5 orang $(3,6 \%)$.

Hasil pengujian validitas dan reliabilitas untuk variabel-variabel dapat dilihat pada Tabel 3 berikut.

Tabel 3 Hasil Uji Validitas dan Reliabilitas Instrumen Penelitian

\begin{tabular}{lccc}
\hline \multicolumn{1}{c}{ Variabel } & $\begin{array}{c}\text { KMO- } \\
\text { MSA }\end{array}$ & $\begin{array}{c}\text { Factor } \\
\text { Loading }\end{array}$ & $\begin{array}{c}\text { Cronbach's } \\
\text { Alpha }\end{array}$ \\
\hline Pendidikan KWU (X1) & 0,770 & $0,751-0,847$ & 0,853 \\
Lingkungan Keluarga (X2) & 0,848 & $0,873-0,930$ & 0,929 \\
Niat berwirausaha (Y) & 0,936 & $0,790-0,896$ & 0,946 \\
\hline
\end{tabular}

Data pada Tabel 3 memperlihatkan bahwa instrumen-instrumen variabel penelitian memenuhi cut off untuk pengujian validitas dan reliabilitas sehingga dapat disimpulkan instrumen-instumen tersebut valid dan reliabel. Hasil pengujian normalitas menggambarkan data berdistribusi normal dengan indikator nilai Kolmogorov Smirnov masing-masing variabel sebesar 0,21; 0,18; dan 0,81. Data menyebar di sekitar garis normal. Hasil pengujian multikolinieritas menunjukkan data terbebas dari multikolinieritas. Pengujian heteroskedasitas menunjukkan bahwa data terbebas dari heteroskedasitas dengan indikator sebaran dari titik-titik scatter plot tidak membentuk pola tertentu dan tersebar antar sumbu Y.

\section{Pengujian Hipotesis}

Pengujian pengaruh beberapa variabel independen terhadap variabel dependen dilakukan dengan analisis regresi berganda. Hasil pengolahan data dapat menjelaskan hasil pengujian hipotesis pada Tabel 4.

\section{Hasil Uji Determinasi (R Square)}

Tabel 4 Hasil Uji Determinasi

\begin{tabular}{ccccc}
\hline Model & $\mathbf{R}$ & $\boldsymbol{R}$ Square & $\begin{array}{c}\text { Adjusted } \\
\boldsymbol{R} \text { Square }\end{array}$ & $\begin{array}{c}\text { Std.Error of } \\
\text { the Estimate }\end{array}$ \\
\hline 1 & 0,886 & 0,785 & 0,781 & 2,97172 \\
\hline
\end{tabular}


Berdasarkan data pada Tabel 4, dapat dilihat dari koefisien determinasi ( $R$ Square) sebesar 0,785. Artinya variabel niat berwirausaha dipengaruhi oleh variabel pendidikan kewirausahaan dan lingkungan keluarga sebesar 78,5\% dan sisanya sebesar $21,5 \%$ dipengaruhi oleh variabel lain.

\section{Hasil Uji Statistik F}

Uji F (uji anova) digunakan untuk menguji pengaruh variabel indenpenden, apakah variabel independen yang berpengaruh signifikan secara bersama-sama terhadap variabel dependen. Hasil uji anova terlihat pada Tabel 5.

Tabel 5 Hasil Uji Anova

\begin{tabular}{ccc}
\hline Model & F & Sig. \\
\hline Regression & 249,466 & 0,000 \\
\hline
\end{tabular}

Hasil regresi pada Tabel 5 terlihat bahwa nilai $\mathrm{F}$ hitung sebesar 249,466 dengan nilai sig sebesar 0,000 (lebih kecil dari 0,05) sehingga model regresi dapat digunakan untuk memprediksi pengaruh pendidikan kewirausahaan dan lingkungan keluarga terhadap niat berwirausaha.

\section{Hasil Uji Statistik t (Uji t)}

Uji t dilakukan untuk mengetahui apakah variabel independen berpengaruh terhadap variabel dependen secara parsial. Hasil uji t terlihat pada Tabel 6.

Tabel 6 Hasil Uji t

\begin{tabular}{lccc}
\hline \multicolumn{1}{c}{ Model } & $\begin{array}{c}\text { Unstandardized } \\
\text { Coefficients }\end{array}$ & $\boldsymbol{t}$ & Sig. \\
\hline (Constant) & 3,772 & 2,827 & 0,005 \\
Kewirausahaan & 0,79 & 8,117 & 0,000 \\
Lingkungan Keluarga & 0,763 & 6,764 & 0,000 \\
\hline
\end{tabular}

Berdasarkan pengujian regresi yang dilakukan seperti Tabel 6, maka diperoleh nilai koefisien regresi nilai konstan adalah sebesar 3,772 yang artinya jika diasumsikan variabel independen tetap, maka niat berwirausaha akan berubah sebesar 3,772. Nilai koefisien regresi dari pendidikan kewirausahaan adalah sebesar 0,796 yang artinya setiap penambahan pendidikan kewirausahaan, maka niat berwirausaha akan meningkat 0,796 . Nilai koefisien regresi dari lingkungan 
keluarga adalah sebesar 0,763 yang artinya setiap penambahan lingkungan keluarga, maka niat berwirausaha akan meningkat 0,763 .

Hasil pengujian regresi yang dilakukan terlihat tingkat signifikan untuk variabel pendidikan kewirausahaan sebesar 0,000, nilai signifikansi tersebut kecil dari alpha $(0,000<0,05)$, sehingga dapat disimpulkan bahwa pendidikan kewirausahaan berpengaruh terhadap niat berwirausaha. Pendidikan kewirausahaan yang diberikan melalui mata kuliah Kewirausahaan akan mempengaruhi mahasiswa untuk menjadi wirausaha (Utami, 2016; Anggles dan Memarista, 2017; Chandra dan Budiono, 2019, Prasetyo, 2019).

Hipotesis kedua yaitu terdapat pengaruh yang signifikan lingkungan keluarga terhadap niat berwirausaha. Dengan melihat nilai signifikansinya yaitu sebesar 0,00 lebih kecil dari 0,05, sehingga dapat disimpulkan bahwa terdapat pengaruh yang signifikan lingkungan keluarga terhadap niat berwirausaha. Orang tua yang memiliki profesi sebagai wirausaha akan mepengaruhi anak-anaknya untuk menjadi seorang wirausaha (Utami, 2016; Khoir, dkk., 2019).

\section{SIMPULAN}

Berdasarkan hasil analisis data, maka dapat disimpulkan bahwa pendidikan kewirausahaan dan lingkungan keluarga berpengaruh terhadap niat berwirausaha pada mahasiswa di Universitas Bung Hatta sebesar 78,5\% dan sisanya sebesar $21,5 \%$ dipengaruhi oleh variabel lain.

\section{DAFTAR PUSTAKA}

Adi, A. 2016. Analisis Penyebab Tingginya Pengangguran Sarjana di Kecamatan Simeulue Barat Kabupaten Simeulue. Aceh: Universitas Teuku Umar. Skripsi tidak diterbitkan.

Anggles, S. N. \& Memarista, G. 2017. Faktor-Faktor yang Mempengaruhi Niat Mahasiswa untuk Berwirausaha. Agora, 5(1): 1-8.

Basrowi. 2014. Kewirausahaan untuk Perguruan Tinggi. Bogor: Ghalia Indonesia.

Badan Pusat Statistik. 2019. Tingkat Pengangguran Terbuka (TPT) di Sumatera Barat sebesar 5,33 persen dalam https://sumbar.bps.go.id/pressrealease/ 2019/11/05/744/agustus-2019--tingkat-pengangguran-terbuka--tpt--disumatera-barat-sebesar-5-33-persen.html. Diakses 24 April 2020. 
Chandra, R. A. \& Budiono, H. 2019. Pengaruh Pendidikan Kewirausahaan terhadap Niat Berwirausaha yang Dimediasi Efikasi Diri Mahasiswa Manajemen. Jurnal Manajerial dan Kewirausahaan, 1(4): 645-655.

Ghozali, I. 2013. Aplikasi Analisis Multivariate dengan Program SPSS 21 (7th $E d$.). Semarang: Universitas Diponegoro.

Haqq, I., Hasby, M., Sebayang, Frida, A., \& Haviz, M. 2018. Faktor-Faktor yang Mempengaruhi Minat Entrepreneur (Studi Kasus: Mahasiswa Fakultas Ekonomi dan Bisnis Universitas Islam Bandung. Prosiding Ilmu Ekonomi, 4(2): 142-149.

Kementerian Perdagangan. 2018. Pengembangan Wirausaha RI Tertinggal dari Malaysia dan Thailand dalam :https:////www,liputan6.com/bisnis/read/ 4014979/pengembangan-wirausaha-ri-tertinggal-dari-malaysia-danThailand. Diakses 22 April 2020.

Khoeriyah, Y., Muamar, A., \& Bakhri, S. 2019. Pengaruh Pendidikan Kewirausahaan dan Keluarga terhadap Minat Wirausaha Darut-Tauhid AlIshlah Cirebon. Al-Mustashfa: Jurnal Penelitian Hukum Ekonomi Islam, 4(1): 327-336.

Khoir, M. F., Nosita, F., \& Asruni. 2019. Faktor-Faktor yang Mempengaruhi Minat Berwirausaha pada Mahasiswa STIE Pancasetia Banjarmasin. Jurnal Ilmiah Ekonomi Bisnis (JIEB), 5(3): 255-262.

Komara, E. 2014. Strategi Perguruan Tinggi dalam Mewujudkan Enterpreneurial Campus. Jurnal Kajian Pendidikan, 4(2): 255-262

Laine, L., Tynjälä, P., Eteläpelto, A., \& Hämäläinen, R. 2019. Students' SelfReported Learning Outcomes after a Business Start-Up Education Program. International Journal of Training Research, 17(2): 98-115.

Prasetyo, E. 2019. Evaluasi Peran Pendidikan Kewirausahaan pada Sekolah Menengah Kejuruan. Edukasi: Jurnal Pendidikan, 17(2): 172-182.

Ratnasari, E., Hakim, A., \& Hayat, A. 2013. Implementasi Program Mahasiswa Wirausaha (PMW) dalam Mewujudkan Mahasiswa Enterpreneur (Studi pada Universitas Brawijaya Malang. Jurnal Administrasi Publik (JAP), 1(6): 1276-1285.

Sugiyono. 2011. Metode Penelitian Kuantitatif, Kualitatif, dan R\&D. Bandung: Alfabeta.

Suharti, L. \& Sirine, H. 2011. Faktor-Faktor yang Berpengaruh terhadap Niat Kewirausahaan (Entrepreneurial Intention) (Studi terhadap Mahasiswa Universitas Kristen Satya Wacana, Salatiga). Jurnal Manajemen dan Kewirausahaan, 13(2): 124-134.

Utami, S. 2016. Faktor-Faktor yang Mempengaruhi Minat Mahasiswa Berwirausaha (Studi Kasus Mahasiswa Fakultas Ekonomi dan Bisnis Islam UIN Walisongo Semarang). Semarang: UIN Walisongo. Skripsi tidak diterbitkan.

Zimmerer, W. T. 2002. Essentials of Entrepreneurship and Small Business Management. Third Edition. New York: Prentice-Hall. 